\title{
THE VARIOUSNESS OF "FEDERAL LAW": COMPETENCE AND DISCRETION IN THE CHOICE OF NATIONAL AND STATE RULES FOR DECISION
}

\section{Paul J. Mishkin ${ }^{\prime}$}

As the national government expands into widening realms of activity, its operations ramify into myriads of new and existing legal relationships. The Government itself is inevitably brought into increasing numbers of diverse contacts with private individuals. Implications are felt in the actions and relations of private persons among themselves. The question of what law, state or federal, and in what combinations, should govern the several parts of these different relationships thus becomes more frequent and pressing.

Often, Congress has furnished the answer, either by providing the substantive rule for decision or by explicit reference to state law. ${ }^{1}$ Where such legislation exists, it would generally seem to conclude the matter. $^{2}$ But inevitably issues arise that have not been resolved legislatively, and the choice of what law to apply devolves upon courts compelled by pending litigation to provide an answer. This article is concerned with the exercise of that choice. ${ }^{3}$

$\dagger$ Associate Professor of Law, University of Pennsylvania. A.B., 1947, LL.B., 1950, Columbia University. Member of the New York Bar.

1. Perhaps the best known example of the latter is found in the Federal Tort Claims Act, 28 U.S.C. $\$ \$ 1346(\mathrm{~b}), 2672,2674$ (1952). For other instances, see, e.g., Immigration and Naturalization Act, 66 STAT. 171 (1952), 8 U.S.C. \$\$ 1101 (b) (1), (c) (1) (1952); Social Security Act, 49 STAr. 620 (1935), as amended, 42 U.S.C. $\$ 416(\mathrm{~h})(1)(1952)$.

2. There may, of course, be a possible question as to the reach of congressional power. Needless to point out, such questions are no longer as frequent as they once were. In any event, it is "the great fact of political science that ultimate questions often do not have to be faced in successful collaborative living." Hart. The Relations Between State and Federal Law, 54 Colum. L. Rev. 489, 507-8 (1954). The distribution of power in a federal system is not made solely in the determination of the dramatic issues of power conflict; the more day-to-day problems of choice of governing law play at least as important a role. See Hart \& WeChsLer, The Federal Courts AND TEE FEDERAL SYSTEM xi (1953). It is with these latter problems that this paper is concerned. Whenever reference is made herein to congressional action, its validity is assumed.

3. Analytically, the problem breaks down along the same basic lines whether the government activity to which the particular issue is related is of a "regulatory" nature or is more a "corporate" operation. However, legislation establishing the former type is more likely to be articulate about the substantive policies sought to be promoted and to provide rules for decision of the central problems; consequently, issues left for judicial determination are more likely to be seen simply in terms of statutory con- 


\section{Judicial Competence to Choose "Federal Law": Erie Railroad AND Clearfield Trust}

Until comparatively recently, identification of a specific source of applicable law was hardly treated as a problem. The narrower range of government activity was undoubtedly a contributing cause. Also important, however, was the hegemony of the doctrine of Swift v. Tyson, ${ }^{4}$ under which the federal courts had power to frame their own "general law" rule for the vast bulk ${ }^{5}$ of common law issues presented to them. Such an approach is not calculated to focus attention on the question of law sources. ${ }^{6}$

Erie R.R. v. Tompkins, ${ }^{7}$ ending the regime of this "general law" in the federal courts, projected the source of law question into sharp relief. Although Erie's holding that a federal court was bound to apply state law came specifically in a case brought within the jurisdiction of a national tribunal only by reason of diversity of citizenship, its impact was immediately felt more widely, extending to litigation directly involving the United States. ${ }^{8}$ Insofar as Erie represented a reversal of

struction and "legislative intent." Though other considerations may well be pertinent in such a "regulatory" context, the full range of considerations appears more readily in regard to the more "institutional" forms of government activity. Moreover, courts have been somewhat more articulate as to this range in the context of the latter type of problem. This paper will therefore focus primarily on questions of that kind, although, as indicated, it is believed that the general analysis applies more widely. The terms "congressional program" and "government program" are used generically to refer to a body of legislation establishing federal activities or policies of either type.

4. 41 U.S. (16 Pet.) 1 (1842).

5. The obligation to follow state law remained as to matters deemed "strictly local, that is to say, to the positive statutes of the state, and the construction thereof adopted by the local tribunals, and to rights and titles to things having a permanent locality, such as the rights and title to real estate, and other matters immovable and intra-territorial in their nature and character." Id. at 17-18.

6. Identification of the source of governing law-state or federal-could still have been important in special contexts; for example in regard to Supreme Court review of state courts, Murdock v. City of Memphis, 87 U.S. (20 Wall.) 590 (1875), or with reference to original jurisdiction in the lower federal courts over cases "arising under" national law, 18 Srar. 470 (1875). Where, however, jurisdiction was established on the basis of the parties to the litigation, such a determination would generally not be required. For purposes of this paper, it is particularly significant that from the Judiciary Act of 1789 on, original federal jurisdiction has been established for any actions brought by the United States (subject at times to various jurisdictional amount requirements). 1 STAT. 73, 77, 78 (1789), 3 STAT. 244, 245 (1815), 18 STAT. 470 (1875), 28 U.S.C. $\$ 1345$ (1952). In such suits it was thus unnecessary specifically to identify the sources of governing law, and the matter was left quite unclear. What general inferences might be drawn from the period preceding Erie $v$. Tompkins have been stated thus: "The Court's opinions, though vacillating and conflicting in their suggestions, were long open to the interpretation that the United States, while protected by the Constitution from discriminatory state action, and perhaps certain other special forms of state control, was nevertheless governed generally in its ordinary proprietary relations by state law." Hart, supra note 2 , at 533 .

7. 304 U.S. 64 (1938). See note 16 infra.

8. See Note, 53 CoLUM. L. REv: 991, 999-1000 and cases cited n.51 (1953); see also the quotation in text at note 72 infra; cf. Hill, The Erie Doctrine in Bankruptcy, 66 HARV. L. REV. 1013, 1033-35 (1953). 
attitude and expressed a strong policy favoring a single substantive rule on a given issue regardless of the court in which the case is presented, that extension is undoubtedly warranted; issues related to operations of the national government may conceivably arise in either federal or state courts and in such cases, as elsewhere, the source of the governing rule should not turn upon litigants' choice of forum. In this aspect, Erie serves to focus the general policy of identifying the appropriate source of authority as to any issue regardless of the courtstate or federal-in which the question is presented.

However, insofar as Erie represents authority for the required application of state law by federal courts, it is not controlling on problems implicated in the operation of a congressional program. From this aspect, Erie's basic holding was a determination that the particular subject matter involved was beyond the law-making competence of the federal courts; that the area was one where state law governed of its own authority, and the mere grant of jurisdiction to adjudicate a case did not carry with it the power to declare an independent "general" rule displacing that authority. ${ }^{9}$ These propositions are inapposite to problems which bear substantial relation to an established federal operation. ${ }^{10}$ As to such questions, state law cannot govern of its own force; there must be competence in the federal judiciary to declare the governing law.

Such competence is essential to the effective implementation of the legislative powers committed to the national government by the Con-

9. Whether this lack of competence is of statutory or constitutional dimensions was a subject of dispute in the Erie case and has not, of course, been finally settled. A recent Supreme Court decision supports the view that the disability is constitutional. Bernhardt v. Polygraphic Co., 350 U.S. 198 (1956). See also Hill, supra note 8, at 1031-33. For present purposes, at least, this issue need not be resolved.

What is important here is that this holding of lack of judicial competence is the essential basis of the rationale underlying the subsequent developments of the "Erie doctrine," see text at notes 26-53 infra, and this is so regardless of which authoritative base is relied upon.

10. Except, possibly, to the extent that they tend to negate any attempt to establish power to declare substantive law in suits to which the United States is party plaintiff, simply from the grant of federal jurisdiction to adjudicate such cases. To be sure, Erie would not be conclusive on that question, for the functions of the diversity-of-citizenship and United States-a-party jurisdictional grants are distinguishable, and there are situations where power to declare governing law must be implied from a grant of jurisdiction. For example, in suits between two states in the United States Supreme Court, the Court must be able to declare the substantive rule (though there be no further authority than the jurisdictional grant); certainly neither party-State's law could be considered binding. See HART \& WECHSLER, op. cit. supra note 2 , at $243-45$.

Nevertheless, Erie would tend to cast doubt on implication of law-making power simply from the grant of jurisdiction over suits brought by the United States, if only because (1) it establishes that jurisdictional grants do not necessarily entail such a power; and (2) it expresses a strong policy against differences in governing law being based on choice of tribunal (a problem not present in suits between states). See also Note, 53 Colum. L. REv. 991, 997 (1953); Comment, 40 CoRNELI L.Q. 561, 576-77 (1953). 
stitution. To be sure, within the central structure, those powers are granted to the Congress, ${ }^{11}$ and, for various good reasons ${ }^{12}$ such grants cannot be taken directly to authorize judicial law-making of equal scope. $^{13}$ At the same time, the separation of powers cannot be watertight; exclusive reliance upon statutory provision for the solution of all problems is futile. Beyond the political realities which will at times compel congressional by-passing of any issue-thus leaving it open until pending litigation forces court resolution-lie such simpler pressures as shortness of time and, perhaps most important, the severe limits of human foresight. Together, these factors combine to make the concept of statutory enactment as a totally self-sufficient and exclusive legislative process entirely unreal. ${ }^{14}$ At the very least, effective Constitutionalism requires recognition of power in the federal courts to declare, as a matter of common law or "judicial legislation," rules which may be necessary to fill in interstitially or otherwise effectuate the statutory patterns enacted in the large by Congress. In other words, it must mean recognition of federal judicial competence to declare the governing law in an area comprising issues substantially related to an established program of government operation. ${ }^{15}$

These propositions seem directly inferable from our basic constitutional structure. Yet, as indicated earlier, the Erie decision ${ }^{16}$

11. E.g., U.S. Consr. art. I, \& 8.

12. Some of the more obvious of these reasons pertain to the separation of powers within the central government-including, of course, the idea that policy should be made primarily by the politically responsible body. Equally important, however, are considerations of federal-state relations. Although it might seem that vis-a-vis the states it would make no difference which agency of the central government exercised the power to declare supervening law, this ignores the political structure which gives the states per se very significant power in the Congress-to a degree hardly paralleled in the judicial structure. See Wechsler, The Political Safeguards of Federalism: The Role of the States in the Composition and Selection of the National Government, 54 ColUM. I. REv. 543 (1954).

13. It is interesting to note, in this connection, that the specific factual situation of the Erie case-an accident between a pedestrian and a railroad train-might conceivably have been within the reach of congressional power over interstate commerce. This question was not considered in the Supreme Court decision, and quite properly so; in that situation, even clearly established legislative power would not automatically imply law-making competence in the federal courts.

14. See Jackson, J. concurring in D'Oench, Duhme \& Co. v. FDIC, 315 U.S. 447, 470 (1942).

15. A possibly more precise way of stating the reach of this power might be to say that it must extend to any issue as to which a tenable (i.e., non-frivolous) claim can be made that the decision could have impact on the operation of congressional legislation. Compare the concept of "protective jurisdiction" and its suggested scope in Mishkin, The Federal "Question" in the District Courts, 53 CoLum. L. REv. 157, 184-96 (1953).

As will appear more fully hereafter, it is unnecessary to attempt to chart these boundaries any more specifically at this time. For in many areas of undoubted federal competence, adoption of state law is indicated, and functionally the areas of competence may well shade off imperceptibly into those where state law governs of its own force.

16. Reference is made throughout this paper to the "Erie decision." Technically, that case can be viewed as an interpretation of the Rules of Decision Act, the present 
seemed to create some question of their correctness. Five years thereafter, however, such doubts were laid to rest by the Supreme Court in Clearfield Trust Co. $v$. United States, ${ }^{17}$ which presented the question of whether state or federal law governed recovery on a guarantee of prior endorsements on a government check. The Court said:

"We agree with the Circuit Court of Appeals that the rule of Erie R.R. Co. v. Tompkins . . does not apply to this action. The rights and duties of the United States on commercial paper which it issues are governed by federal rather than local law. When the United States disburses its funds or pays its debts, it is exercising a constitutional function or power. . . . The authority to issue the check had its origin in the Constitution and the statutes of the United States and was in no way dependent on the laws of Pennsylvania or any other state. . . . The duties imposed upon the United States and the rights acquired by it as a result of the issuance find their roots in the same federal sources. . . . In the absence of an applicable Act of Congress it is for the federal courts to fashion the governing rule of law according to their own standards. . . ." 18

Though this language speaks directly only of the United States, plaintiff in the action before the Court, the basic rationale underlying the passage would seem equally apposite to any issue bearing a substantial relation to an established national government function. ${ }^{19}$

version of which (containing minor changes) is as follows: "The laws of the several states, except where the Constitution or treaties of the United States or Acts of Congress otherwise require or provide, shall be regarded as rules of decision in civil actions in the courts of the United States, in cases where they apply." 28 U.S.C. $\$ 1652$ (1952). Moreover, the problem discussed in the text could be viewed entirely as a matter of the interpretation of that act. Cf. Note, 53 CoLUM. L. REv. 991 (1953). In these terms, it could be said that there is a substantial penumbra surrounding each program of congressional legislation where indeed "the Constitution ... or Acts of Congress otherwise require" than that state law be automatically applied.

However, as even quick perusal will indicate, the terms of the act are "almost perversely uninformative." Moreover, judicial authority has often said that the act "is merely declarative of the rule which would exist in the absence of the statute." E.g., Mason v. United States, 260 U.S. 545, 559 (1923), Guaranty Trust Co. v. York, 326 U.S. 99, 103-04 (1945). For these reasons, the discussion throughout this paper is couched in terms of the criteria believed to play-or which ought to play-an important role in the decision of these questions. From this aspect, the Rules of Decision Act is significant principally as an expression of an underlying policy, and will be referred to where relevant in that regard.

17. 318 U.S. 363 (1943). A full statement of the facts and a detailed analysis of the case may be found in the text at notes $132-47$ infra.

18. Id. at 366-67.

19. The line of argument used in Clearfield is based upon the federal nature of the function involved, rather than upon the fact of the Government being a party to the specific litigation. That this must be its rationale is indicated by (a) the fact that the Court did not rely at all on the grant of federal jurisdiction over litigation brought by the United States (as well as the general problems of any attempt to imply lawmaking power on that basis, see note 10 supra); (b) the impossibility of limiting any such rule solely in terms of parties to the litigation; see, e.g., American Houses, Inc. v. Schneider, 211 F.2d 881 (3d Cir. 1954); cf. S.R.A., Inc. v. Minnesota, 327 U.S. 558 (1946); and (c) the Court's citation of an earlier case in which a similar ap- 


\section{Federal Incorporation of State Law: The Irrelevance of Erie}

The passage just quoted presents the issue as whether Erie applies, thus presenting the alternatives as either the Erie doctrine or "ffederal law." Since the Erie doctrine basically represents a determination of a lack of competence in the federal courts to do other than apply the state law, ${ }^{20}$ this is an accurate statement of the issue only if the term "federal law" is taken to refer to federal judicial competence to choose which law shall govern. However, that term ${ }^{21}$ may seem to imply more: not only the power to choose, but also the exercise of that power by a choice in favor of a single, federally-created substantive rule. The latter is not a necessary corollary of the former. The power to choose may also be exercised by adopting state law as the governing rule-by incorporating the local rules for decision as the "federal law" for this purpose. ${ }^{22}$ The Clearfield opinion itself recognized this second possibility, ${ }^{23}$ and proceeded from the quoted passage to make a separate

proach had been used though the Government was not directly involved. See Deitrick v. Greaney, 309 U.S. 190 (1940), discussed in text at notes 65-72 infra; see also Sola Elec. Co. v. Jefferson Elec. Co., 317 U.S. 173 (1942).

For general discussions of the limits of Erie and of the impact of Clearfield Trust, see HART \& WECHSLER, op. cit. supra note 2, at 679-708; Hart, supra note 2, at 525-35; Reifenberg, Federal Common Law, 30 OrE. I. Rev. 164 (1951); Keeffe, Gi1hooley, Bailey \& Day, Weary Erie, 34 CoRnell L. Q. 494 (1949); Gorrell \& Weed, Erie Railroad: Ten Years After, 9 OHIo ST. L.J. 276 (1948); Comment, Erie Limited: The Confines of State Law in the Federal Courts, 40 CoRNELL, L. Q. 561 (1955); Note, Clearfield: Clouded Field of Federal Common Laze, 53 CoLUm. L. REN. 991 (1953); Note, Exceptions to Erie v. Tompkins: The Survival of Federal Common Laze, 59 HARV. L. REv. 966 (1946).

20. See text at note 9 supra. Of course, in one sense, the determination of whether or not this competence exists is itself a federal question, to be decided under the Constitution and existing legislation. From this point of view, Erie itself represents a determination of "federal law." But since, at least in theory, there was no discretion to decide otherwise-and in any event, the decision of this question involves a different order of considerations-it is not analytically helpful to refer to it that way, and that is not the usage employed in the text.

21. And also the phrase "fashion the governing rule of law" at the end of the passage quoted in text at note 18 supra.

22. "The scope of a federal right is, of course, a federal question, but that does not mean that its content is not to be determined by state, rather than federal law." De Sylva v. Ballentine, 351 U.S. 570,580 (1956), discussed in text at notes 94-112 infra; RFC v. Beaver County, 328 U.S. 204 (1946); Board of County Comm'rs v. United States, 308 U.S. 343 (1939) ; see also Hart, supra note 2, at 529-30.

Some of the clearest instances of federal incorporation of state law are statutory, e.g. Federal Tort Claims Act, 28 U.S.C. $\$ 1346($ b) (1952); as a result of the explicit legislative direction, articulation of some of the implications of such incorporation has quite frequently occurred with reference to such statutes. Though the considerations underlying the two methods of adoption may differ considerably, some of the implications of such action are quite similar, and the legislative development has been drawn upon as a parallel in some of the following text discussion.

23. "In our choice of the applicable federal rule we have occasionally selected state law." 318 U.S. at 367. This seems somewhat of an understatement; but see the formulation in De Sylva v. Ballentine, supra note 22, and note that Mr. Justice Douglas, author of the Clearfield opinion, dissented in that case; see also Hart, supra note 2 and cases cited in note 22 supra. 
express determination that in the situation before the Court a single nationwide substantive rule should be applied. ${ }^{24}$ But it did not dwell to any significant extent on the distinction between competence to choose and the actual choosing, and the independence of the two matters has not always been perceived. ${ }^{25}$

What makes the distinction important is that if the issue is seen only as a choice between a federal rule of substance and Erie, the problem appears much more difficult than need be. For the implication of this breakdown is that any application of state law-whether of its own force or by way of federal incorporation-is subject to the entire body of rules and doctrine which developed in the aftermath of Erie. In fact, however, these two modes of using local law may involve substantially different approaches, particularly as to the methods and scope of applying state law. Much of the doctrine as to such methods and scope which was developed under Erie is premised upon that case's basic concept of lack of federal judicial competence in the pertinent area. Therefore, it is not necessarily applicable where local law is adopted as the discretionary federal choice in an area of undoubted competence. ${ }^{26}$

The same questions of scope and technique which arose in the aftermath of Erie call for independent analysis in regard to federally incorporated state law. This is not to suggest that the answers will always be uniformly different from those found in the Erie area. The situations in which state law is absorbed into federal are not unitary. As will be detailed in the next section, the considerations which lead to selection of local law in one context may vary greatly from those operative in other circumstances; in any given situation, the extent of incorporation and the techniques for ascertaining what local law is must be determined by the particular considerations which established the advisability of adopting that law. For example, there may be situations where state law is chosen only because of special difficulty in the judicial framing of a definite federal rule on a specific issue in an

24. "But reasons which may make state law at times the appropriate federal rule are singularly inappropriate here." 318 U.S. at 367 . As to this question, see text at notes 132-47 infra.

25. E.g., compare United States v. Matthews, 139 F. Supp. 683, 688-89 (N.D. Cal. 1956) with United States v. Kramel, 234 F.2d 577 (8th Cir. 1956); cf. Note, Exceptions to Erie v. Tompkins: The Survival of Federal Common Law, 59 Harv. L. REV. 966 (1946).

26. $C f$. Levinson v. Deupree, 345 U.S. 648 (1953), an action in admiralty for wrongful death, as to which maritime law incorporates state law (including the time limit for bringing of the action); under the prevailing state rule, an essential amendment of pleadings was barred by the statute of limitations; the issue was whether this was binding on the federal court. The Court said:

"The United States District Court ... heard this suit sitting in admiralty. Its jurisdiction did not derive from diversity of citizenship; indeed there was no such diversity. Erie R.R. Co. v. Tompkins. . is irrelevant. . ." Id. at 651 ; and compare Bomar v. Keyes, 162 F.2d 136, 140-41 (2d Cir.), cert. denied, 332 U.S. 825 (1947), writh Ragan v. Merchants Transfer \& Warehouse Co., 337 U.S. 530 (1949). 
area otherwise totally national. ${ }^{27}$ Under such circumstances, the extent and method of adopting local rules may be quite limited, ${ }^{28}$ particularly as compared to the situation where a principal motive behind adoption is a need to integrate the operation of a federal program with the daily routine activities of citizens under the laws of the several states. ${ }^{29}$ Indeed, it may well be that in the latter situation both the scope and techniques of adoption should be indistinguishable from those applicable where state law governs of its own force. What is important for present purposes is not the degree of resulting difference, but that the question of how much there will be is itself a matter to be determined by the exercise of federal discretion. The main point here is that a decision to apply state law as a matter of federal incorporation does not necessarily carry with it the obligation to adhere to the range and techniques which have been held to govern under Erie; there remains a freedom, after decision to incorporate local law, to control the extent and methods of that adoption which is not present when a determination has been made that state law will apply because the court has no competence to do otherwise. Content may be lent to these propositions by examining in somewhat more detail a few of the more important instances where this difference is pertinent.

\section{The Scope of Decision}

Most pervasive, perhaps, is the principle that a decision to apply state law as a matter of federal judicial incorporation may frequently

27. As, for example, in establishing a limitations period for federal causes of action as to which Congress has provided no guidance. E.g., Cope v. Anderson, 331 U.S. 461 (1947); Campbell v. Haverhill, 155 U.S. 610 (1895); cf. Holmberg v. Armbrecht, 327 U.S. 392 (1946). For a general analysis of the considerations as to the extent and method of using local law in this situation, and a review of the decisions, see Note, Federal Statutes Without Limitations Provisions, 53 CoLum. L. REv. 68 (1953).

28. "The failure of a federal statute to provide a limitation period is difficult to remedy by judicial action, but the courts are well situated to write federal law on the subsidiary issues involved in the limitations of actions." Id. at 72; but cf. Hill, State Procedural Law in Federal Non-Diversity Litigation, 69 HARV. L. REv. 66, 99 (1955).

29. As, for example, in determining the liability of an auctioneer who sells a cow subject to a chattel mortgage held by the Farmers Home Administration, United States v. Kramel, 234 F.2d 577 (8th Cir. 1956), or in deciding a dispute arising among private parties involving normally circulating government bearer bonds. Bank of America National Trust v. Parnell, 352 U.S. 29 (1956); discussed in the text at notes 113-31 infra. Cf. RFC v. Beaver County, 328 U.S. 204 (1946), involving a federal statute which provided that certain property of the RFC should not be subject to state or local taxes but denied the exemption as to "real property." In holding that an unusual Pennsylvania definition of "real property" could be applied, the Court said "Concepts of real property are deeply rooted in state traditions, customs, habits, and laws. Local tax administration is geared to those concepts. To permit the States to tax, and yet to require them to alter their long-standing practice of assessments and collections, would create the kind of confusion and resultant hampering of local tax machinery which we are certain Congress did not intend. The fact that Congress subjected Defense Plant Corporation's properties to local taxes 'to the same extent according to its values as other real property is taxed' indicated an intent to integrate congressional permission to tax with established local tax assessment and collection machinery." Id at 210. 
be made as to a single issue at a time. ${ }^{30}$ Where state law is determined to govern of its own force, that determination generally means that all issues in the subject-matter area will be similarly governed by local law. This follows almost inevitably from the idea that local law governs of its own authority; in our federal system, the authority of states runs over whole areas of law, and determinations of jurisdiction will thus generally cover such areas. Whether state law is to be incorporated as a matter of federal common law, however, involves the different problem of the relationship of a particular issue to a going federal program. The question of judicial incorporation can only arise in an area which is sufficiently close to a national operation to establish competence in the federal courts to choose the governing law, and yet not so close as clearly to require the application of a single nationwide rule of substance. In such an area the determination of one issue's relationship to the going program will not necessarily determine the relevance of the other issues in the same substantive area; by hypothesis, the area shades off into total federal involvement on one end and complete state law on the other. Thus, while decision of a particular issue may influence the outcome on others, its effect will generally tend to be narrower and less pervasive than when state law is determined to be sovereign.

\section{The Relevance of the Particular Local Rule}

Another difference relates to the content of state law. A decision that state law governs of its own authority is made-at least theoretically and generally in fact ${ }^{31}$ - without consideration of the substance of the particular local rule; once that decision is made, state law is to be applied regardless of what or how varied the treatment of the problem may be throughout the forty-eight states. So long as the local rule is valid, it governs. Where the problem is one of federal adoption, however, a limitation exists which requires some consideration of substance. Since the issue's outcome bears some relationship to a federal program, no rule may be applied which would not be wholly in

30. The question may be as narrow as the interest payable on a federal claim. Cf. Royal Indemnity Co. v. United States, 313 U.S. 289 (1941) ; Board of Comm'rs v. United States, 308 U.S. 343 (1939). And see the problem cases discussed in the next section of this paper. For an instance in an area of legislative incorporation, note the issue which divided the Court in Massachusetts Bonding \& Ins. Co. v. United States, 352 U.S. 128 (1956). Note also that as an issue falls closer to the area where state law governs of its own force, the impact of the holding may be wider. See note 128 infra.

31. The Supreme Court's usual practice in cases involving the scope of the Erie doctrine is to leave questions of what the local law is entirely up to the lower federal courts. Cf. Bernhardt v. Polygraphic Co., 350 U.S. 198 (1956) (Court divided on the question of whether the district court's determination should be final, or whether case should be remanded for court of appeals review of the interpretation of local law; majority remanded directly to the district court). 
accord with that program..$^{32}$ This has two implications. If state law generally would not produce such a result, incorporation may be totally precluded. Moreover, even where state law might be generally adopted on an issue, it would be possible to reject the rule of a particular state whose doctrine on the specific issue was not entirely consistent with federal objectives, though this might mean that state law was incorporated as to forty-six out of the forty-eight states but not the remaining two.33 Furthermore, unlike areas of state law sovereignty, such rejection does not depend upon or imply invalidation of the local rule; that rule might continue in full force as a matter of state law though rejected for federal adoption. ${ }^{34}$

\section{Choosing Which State's Law}

To this point, the discussion has considered "state law" as if there were no question as to which state's law would apply. This might well be the case when all relevant events occurred within the boundaries of a single state, but of course this is not inevitably the situation. Where different parts of a transaction have taken place in more than one jurisdiction, and the governing rule for decision is to be that of a state, it becomes necessary to select which one.

In those subject-matter areas where the states are sovereign, it is clear that they may, within broad limits, adopt their own rules for choice of appropriate state law to govern litigation in their courts growing out of multi-state events. ${ }^{35}$ Moreover, it is also presently established that federal courts, in deciding matters within those areas (and thus within the scope of the Erie doctrine), must apply those local choice-of-law rules of the state within which they sit. ${ }^{36}$

32. "We think the Congressional purpose can best be accomplished by application of settled state rules... so long as it is plain, as it is here, that the state rules do not effect a discrimination against the Government, or patently run counter to the terms of the Act." RFC v. Beaver County, 328 U.S. 204, 210 (1946); cf. De Sylva v. Ballentine, 351 U.S. 570,581 (1956).

33. This is certainly the implication of the cases cited note 32 supra. Moreover, this is precisely the present situation as to measure of damages for wrongful death under the Federal Tort Claims Act, 28 U.S.C. $\$ 2674$ (1952); local law is adopted in all the states except Alabama and Massachusetts. See Massachusetts Bonding \& Ins. Co. v. United States, 352 U.S. 128 (1956).

34. The federal rule would apply, however, whenever the precise issue was litigated, whether in state or federal court.

35. Some federal control is exerted under the due process and full-faith-and-credit clauses of the Constitution. U.S. ConsT. amend. XIV, \& 1 ; art. IV, § 1 . While potential apparently exists under the latter clause for far fuller federal control, it is at present effective in a comparatively few, specific areas. See Cheatham, Federal Control of Conflict of Laws, 6 VAND. L. REv. 581 (1953); Jackson, Full Faith and Credit -The Lareyer's Clause of the Constitution, 45 Colum. L. REv. 1 (1945).

36. Klaxon Co. v. Stentor Elec. Mfg. Co., 313 U.S. 487 (1941); Wells v. Simonds Abrasive Co., 345 U.S. 514 (1953) ; cf. Griffin v. McCoach, 313 U.S. 498 (ig41). Of course, this rule applies only where the issue involved is one deemed to "determine the outcome of the litigation." Throughout the discussion of the Erie doctrine in the text, the issue is assumed to be one which falls within this test. 
It should be clear that the use of varying state choice-of-law rules means that the particular law which will apply to any multi-state transaction cannot be ascertained in advance of litigation (and is then determined, at least indirectly, by the plaintiff's choice of forum). In areas entirely within state sovereignty, this uncertainty now exists generally as among state courts, and if uniformity within each state-as between federal and local courts-is considered of prime importance, then a requirement of conformity by the federal tribunals is certainly supportable. For it is true that establishment of independent choice-oflaw rules applicable only to litigation in the national courts ${ }^{37}$ could produce disparate results from those of the state courts "across the street" in cases whose sole distinguishing characteristic is diverse citizenship of the parties or other similar basis of federal jurisdiction. Nevertheless, it has been cogently argued that even in the Erie area the disadvantages of such disparity are outweighed by other considerations. ${ }^{38}$

When one turns to the area where the federal courts are competent to choose the governing rule of substance-as they are where state law applies only by incorporation-then even that disparity disappears and the other considerations take on increasing force. In the latter area, power to formulate the rule stems from the relevance of the particular issue to an established federal program, and is thus an exercise of the "supreme" 39 substantive powers of the national government. Rules so established would bind state courts in determining the same issues. ${ }^{40}$ No danger of "forum shopping" as between federal and state courts could be created. On the other hand, unless a nationwide choice-of-law rule is promulgated, the danger of such "shopping" as among various states would continue, with, as already indicated, consequent uncertainty and unpredictability regarding the governing law. While there may be some issues related to a federal program where such a result might still be indicated, it would seem more likely, as a general rule, that a national program would be facilitated if state law, where applicable on relevant issues, could be identified with fair certainty during normal operations; multi-state transactions can hardly be considered unusual in relation to a national program. Moreover, and

37. This would not be the case if federal choice-of-law rules were adopted under authority of the full-faith-and-credit clause of the Constitution, art. IV, $\S 1 ; 28$ U.S.C. $\$ 1738$ (1952); for such rules would be binding upon state courts too. See articles cited note 35 supra.

38. HART \& WECESIER, op. cit. supra note 2, at 633-36; Hart, supra note 2 , at 513$15,541-42$.

39. U.S. CoNst. art. VI, cl. 2.

40. Ibid. It may be worth noting that this line of reasoning applies throughout the subject of this paper, whenever a decision in favor of a federally formulated rule is under discussion. $C f$. Francis v. Southern Pac. Co., 333 U.S. 445, 450 (1948). 
of at least equal importance, the independent federal choice-of-law rule which would enable the advance selection of the particular state law could be tailored to serve the ends which initially prompted federal incorporation. Thus, for example, where the purpose behind adoption of local law was principally to permit integration of operations under the national program with ordinary commercial practices, ${ }^{41}$ a federally formulated rule could select as determinative that facet of the given type of transaction as to which such "dovetailing" is most essential. Once again, the main point is not that an independent rule must be used for every issue as to which state law is incorporated, but rather that, unlike the Erie area, there is no bar here, even under present law, to use of such a rule where it appears advisable. ${ }^{42}$

\section{Determining What the State Law Is}

The final difference between these two types of state law to be considered here is of a slightly different nature. It is in the techniques to be applied for ascertaining what the local rule is on a given issue. Obviously, this will present a problem only where state law is unclear; where there is a recent decision of the pertinent state's highest court "on all fours" with the pending case, a direction to follow state law needs no elaboration of implimenting techniques. Where, however, the only available precedent is quite old, or distinguishable, or of a lower court (or a combination of these), additional problems are presented. It then becomes possible, if one chooses, to formulate more-or-less specific rules for assessing the weight of such precedent. In the Erie area, the Supreme Court has so chosen. It has developed a series of detailed propositions which attempt with some rigor to control the ascertaining of state law by federal courts. For example, it has held that a decision by a state intermediate appellate court, ${ }^{43}$ or even of some trial courts, ${ }^{44}$

41. See note 29 supra.

42. $C f$. De Sylva v. Ballentine, 351 U.S. 570 (1956), discussed in text at notes 94-112 infra: After holding that the meaning of a term in a federal statute should be determined by state law, the Court implied that it had power to choose not only which state's law, but also what part of that law should govern. Since all contacts in the case in fact involved only one state, the case holds specifically only on the latter question. See also Federal Tort Claims Act, 28 U.S.C. $\$ \$ 1346(\mathrm{~b}), 2672,2674$ (1952) and Social Security Act, 64 STAT. 492 (1935), 42 U.S.C. $\$ 416(h)(1)$ (1952), for examples of statutory choice-of-law rules in federal incorporation of state law.

For general discussion of the problem, and analysis of specific areas along the general lines indicated in the text, see Note, Applicability of State Conflicts Rulles When Issies of State Law Arise in Federal Question Cases, 68 HARV. L. REv. 1212 (1955); cf. Hill, supra note 28, at 100-11.

43. Six Companies v. Joint Highway District No. 13, 311 U.S. 180 (1940); West v. American Tel. \& Tel. Co., 311 U.S. 223 (1940); Stoner v. New York Life Ins. Co., 311 U.S. 464 (1940).

44. Fidelity Union Trust Co. v. Field, 311 U.S. 169 (1940). But cf. King v. Order of United Commercial Travelers, 333 U.S. 153 (1948). 
must be followed "in the absence of more convincing evidence of what the state law is" ${ }^{45}$-and indeed indicated that the unsoundness of the decision could not constitute such "convincing evidence." 46

These rules have been criticized as being too limiting and mechanical, and thus depriving litigants of an intelligent use of the "judicial process" by federal judges. ${ }^{47}$ Putting aside the merits of this issue as to the area governed by Erie, it is in any event true that insofar as rigorous limitation of federal judges may affect litigants' choices of forum and dispose them toward use of state courts, this consequence would not seem of major present significance in the field of diversity jurisdiction. ${ }^{48}$ When one is dealing with issues related to federal operation, however, such discouragement of resort to a federal tribunal ${ }^{40}$ may indeed be a serious and undesirable matter. Where a state court is an available alternative, the result may be less sympathetic treatment of other litigated aspects of the national program; where federal jurisdiction is exclusive, it could conceivably mean discouragement from the enforcement of any rights-or more likely and still important, an abiding sense of injustice at unintelligent treatment. In any of these events, a national program may be significantly hampered.

Moreover, in dealing with an area of federal adoption of state law, rather than Erie, the objective of assuring uniformity as between federal and state tribunals ${ }^{50}$ may be unimportant compared to other considerations which dictated the federal incorporation. Under these circumstances, the necessity for detailed adherence to particular ambiguous state precedents should be measured by these latter considerations.

45. Fidelity Union Trust Co. v. Field, stipra note 44 at 178.

46. See, e.g., West v. American Tel. \& Tel. Co., 311 U.S. 169, 238 (1940) : "We think that the law thus announced and applied is the law of the state applicable in the same case and to the same parties in the federal court and that the federal court is not free to apply a different rule however desirable it may believe it to be, and even though it may think that the state Supreme Court may establish a different rule in some future litigation."

47. For an excellent presentation of the judge's dilemma under these rules, see the opinion of Judge Wyzanski in Pomerantz v. Clark, 101 F. Supp. 341 (D. Mass. 1951). See also Judge Frank's opinion in Richardson v. Commissioner of Int. Rev., 126 F.2d 562, 567 (2d Cir. 1942) ; Corbin, The Lazes of the Several States, 50 Yale L.J. 762 (1941); Broh-Kahn, Uniformity Rum Riot-Extensions of the Erie Case, 31 KY. L.J. 99 (1943); Clark, State Laze in the Federal Courts: The Brooding Ommipresence of Erie v. Tompkins, 55 YAlE L.J. 267 (1946) ; Hart, supra note 2, at 510; HART \& WECESLER, op. cit. supre note 2 , at 628-29.

48. Cf. Wechsler, Federal Jurisdiction and the Revision of the Judicial Code, 13 LAW \& CONTEMP. PROB. 216, 238-39 (1948); HART \& WECHSLER, op. cit. supra note 2 , at 893-97 and articles cited n.1.

49. Assuming that a federal court is available. In many circumstances which federally incorporated state law will be litigable only in the state courts-see Mishkin, supra note 15 , at 165-66. In such cases, of course, the problem considered in the text does not arise.

50. Indeed, where federal jurisdiction is exclusive, as it is in some of these areas, avoidance of "forum shopping" could play no part in the decision to use state law. 
The Supreme Court has frequently recognized that the lower federal judiciary is best acquainted with current state law. ${ }^{51}$ Where, as in the area of our concern, the reasons for using local law can be consciously considered and articulated with reference to particular problems, the wisest general approach might well be to leave it to the integrity and judgment of those lower court judges, acting in the light of the applicable reasons, to ascertain and apply the state law as best they can. ${ }^{52}$ For here, to a far greater degree than in the Erie bailiwick, the costs of attempting to do otherwise can be substantial.

The foregoing discussion has sought to demonstrate that a decision in the terms "state law applies" in fact glosses over an important issue; that it makes a very substantial difference, functionally, whether that decision be reached on the basis that a federal court lacks competence to do otherwise (as in Erie), or because it is deemed a wiser federal choice than a nationwide substantive rule. Exploration of these differences may, inferentially, make state law appear a more acceptable possibility where it would not necessarily entail concurrent adoption of all the doctrine which has been developed under Erie..$^{\text {i3 }}$ If that is so, it only serves to heighten what is in any event a difficult problem: where power of choice exists, what are the criteria for its exercise; under what circumstances should a federal substantive rule be prescribed, and when should state law be incorporated? It is to that problem which we now turn.

\section{Federal Rules of Substance and Adoption of State Law- \\ The Basis of Chorce}

\section{General Considerations}

The extensiveness of the preceding discussion is obviously premised upon the idea that state law plays an important role in areas related to a going national program. It is conceivable that one might accept the substance of the proffered analysis while rejecting its significance, on the theory that the entire role of state law in reference to any federal program is a marginal one-serving only at the outer

51. See note 31 siupra.

52. Indeed, there may be scope in this area for Mr. Justice Stone's understanding of the holding in Erie: "I understand that the basis of our decision in the Pennsylvania railroad accident case is that we follow local law when it is well enough defined so that we know what it is." See Mason, Harlan Fiske Stone: Pillar of the Law 478 (1956).

53. $C f$. the suggestion that "if the federal courts were not bound to follow every anomaly in the local law, particularly those asserted by the lower state tribunals and not yet passed upon by the highest state court, they might not have had such a propensity to confine the Rules of Decision Act to diversity." Note, 53 Colusr. L. Rev. 991 , 1008, n.95 (1953). 
limits as a matrix for fitting the national operation into the general state law structure. Careful students of the subject have concluded otherwise:

"When federal law . . . turns to take up itself the task of affirmative governance of private activity, it might be supposed that state law would cease to play a significant part-save only at the periphery marking the outer bounds of federal power. Precisely the contrary is true. It is in this sphere that the essential incomplete and interstitial nature of federal law is most conspicuously revealed." 54

This pattern reflects deep values of our federal system-not that action of the central government represents an intrusion upon an otherwise perfect system, but rather that Congress legislates against a background of existing state law..$^{55}$ Indeed, Congress has at times legislatively recognized and taken advantage of this fact; on various occasions when its power to displace state law would be unquestionable, it has specifcally adopted that law as the federal rule..$^{56}$

Where Congress has specifically made its choice-either by adoption of state law or by specifying a substantive rule for decisions-that choice of course governs without more. ${ }^{57}$ Where no such direction is provided, and yet the matter at issue is substantially related to a going national program, the selection of the source of governing rule devolves upon the courts. The problem then is identifying the criteria for choice.

In some aspects, this problem resembles that of "interpreting" an ambiguous or indeterminate statute. Highly relevant are all the indicators of "legislative intent" generally employed in such an inquiry, including the broad historical pattern of legislative development in the area, the relationship of the existing statutory scheme to the particular matter at issue and, of course, any relevant data as to specific activity in Congress or its committees. ${ }^{58}$ At times, these inquiries may end the matter. Moreover, even when, as seems fairly frequent, these sources are not conclusive on the point at issue, they may nevertheless provide the framework for careful examination of the consequences of decision 435-36.

54. Hart, supra note 2, at 525-39; HART \& WECHSLER, op. cit. supra note 2 , at

55. See text at note 64 infra.

56. See note 1 supra; cf. the McCarran Act, 59 STAT. 33 (1945), as amended, 15 U.S.C. $\$ \$ 1011-15$ (1952), which turned the regulation and taxation of insurance back to the states (after the Supreme Court had held them to be within congressional con-
trol).

57. See note 2 supra.

58. See Note, $A$ Re-evaluation of the Use of Legislative History in the Federal Courts, 52 Colum. L. REv. 125 (1952). 
each way in terms of what is at stake and which result would best comport with the existing national operation.

But the problem also differs from more usual questions of statutory construction, for it involves not merely arriving at one or another substantive rule for decision, but deciding whether to formulate such a rule at all or to refer the determination to state law. It thus invokes a somewhat different focus even for the inquiries already mentioned, as well as introducing an additional range of considerations having to do with the federal nature of the Union. Take, for example, the examination of the consequences of decision with reference to the existing statutory scheme. In the present context, this would involve consideration not only of the best substantive result on the particular issue, but also balancing against the possible gain from prescribing such a rule, the potential losses from non-integration of the national program with normal state activities.

Moreover, the choice of law issue involves examination of some special factors not generally important in the resolution of a direct substantive question. Thus, for example, the relative roles of the national and state judiciaries come to the forefront in this area in a way not usually pertinent: implications of exclusive federal jurisdiction, effects on the flow of litigation-in areas of concurrent jurisdiction-between national and state courts, and similar matters must be considered specifically. Behind these lie vastly important questions of the distribution of power between national and state governments, not in their dramatic aspect of open constitutional conflict, but in their no less important daily workings. ${ }^{59}$ An attempt will be made to lend content to these general propositions by developing them in the analysis of a series of specific cases. Before doing so, two preliminary comments may be in order.

First, while many of the factual considerations which will be described as relevant here are not unfamiliar to the lawyer, they seem to have gone completely unnoticed at times. Moreover, when they have been treated, counsel's arguments-and consequently opinionsregarding such factors are most often stated in general terms which assert a conclusion without any apparent examination or presentation of underlying data. ${ }^{60}$ At times that omission may be due to difficulty in obtaining the relevant facts, ${ }^{61}$ but in other instances the lack can

59. See note 2 supra.

60. Examples will be found in the discussion of the problem cases to follow.

61. This has limited some of investigation in connection with the discussion of problem cases to follow in this paper, where it is possble that factual data may prove less complete than might be desired. It may be worth noting, however, that counsel in any given case are usually in a good position to obtain the relevant data for that litigation, even where it might not be otherwise generally available. 
only be attributed to a failure to consider them necessary or important. A clear example of the latter may be found where the "facts" are peculiarly within the knowledge of the legal profession. Throughout this area, an important question relates to the advantages of a "uniform" federal rule. Now there are circumstances ${ }^{62}$ where the argument for uniformity depends for its cogency upon the probability of actually having a single nationwide rule. Yet the fact is-presumably well known to the legal profession-that such complete uniformity may be most unlikely as a matter of common law development: the only court in a position to assure that degree of uniformity-the United States Supreme Court-is so burdened with its present work that it is highly improbable that it could undertake effectively to develop detailed substantive rules for any area we are here considering. ${ }^{63}$ Yet the argument for "uniformity" is made in a wide variety of contexts without any reference to this aspect of reality. A greater degree of concreteness is indicated, not only as to this particular matter, but as to analysis of problems in this field generally.

The argument for "uniformity" may also serve to illustrate the second point, though the focus now is not upon its factual likelihood, but rather upon the weight to be assigned to its accomplishment. The importance of uniformity in relation to a particular issue may at times be clearly settled by careful analysis of the given problem-particularly when it is viewed against its legislative background. But more often, perhaps, the force attributed to it in fact depends upon assumptions, only rarely articulated, about our federal system. Thus, not infrequently the call for "uniformity" seems basically to represent a desire for symmetry of abstract legal principles and a revolt against the complexities of a federated system of government. Under such circumstances, the importance assigned to this argument in fact incorporates an implicit judgment about the relative value of federalism. The same point seems to apply more generally as well. Many other factors also contain implicit judgments on the questions of distribution of power between national and state governments. So long as these underlying considerations are not articulated, it is fairly easy, in these days of increasing reliance on and attention to our central government, to underestimate the importance of the states and the accompanying di-

62. Though not always. At times, uniformity within a circuit may itself be of advantage. See the discussion of the second problem case, text at notes 73-93 infra.

63. Even under present conditions, the Supreme Court does not grant certiorari in a significant number of conflicts among the circuits. Stern, Denial of Certiorari Despite a Conflict, $66 \mathrm{HARv}$. L. REv. 465 (1953). Any substantial added volume of litigation would necessarily increase the difficulty of maintaining nationwide uniformity of federal judge-made law. 
versity and diffusion of power. It may also tend to obscure the general pattern of our national structure:

"The fact of the continuous existence of the states, with general governmental competence unless excluded by the Constitution or valid Act of Congress, set the mood of our federalism from the start. The first Congress did not face the problem of building a legal system from the ground up; it started with the premise that the standing corpus juris of the country was provided by the states. . .

"National action has thus always been regarded as exceptional in our polity, an intrusion to be justified by some necessity, the special rather than the ordinary case. This point of view cuts even deeper than the concept of the central government as one of granted, limited authority, articulated in the Tenth Amendment. National power may be quite unquestionable in a given situation: those who would advocate its exercise must none the less answer the preliminary question why the matter should not be left to the states. Even when Congress acts, its tendency has been to frame enactments on an ad hoc basis to accomplish limited objectives, supplanting statecreated norms only so far as may be necessary for the purpose. Indeed, with all the centralizing growth throughout the years, federal law is still a largely interstitial product, rarely occupying any field completely, building normally upon legal relationships established by the states." ${ }^{84}$

The implications of the matters just discussed may appear more clearly in the analysis of particular problems.

\section{Problem Cases}

\section{Case I}

The first case poses a comparatively unadorned problem. A national bank acquired shares of its own stock-in violation of the National Bank Act of $1864 .^{65}$ In order to conceal that acquisition and continued ownership, a director of the bank gave it his personal note, to be carried on the books instead of the stock, on the understanding that the note was not to be paid. Upon the insolvency of the bank, the receiver sues the director on the note; the latter defends on want of

64. Wechsler, supra note 12 , at 544-45. This is the policy expressed by the Rules of Decision Act, see note 16 supra, the importance of which lies principally in the expression it is of congressional recognition of this historical fact and policy. In a very real sense, underlying every issue as to the promulgation of a federal substantive rule is the question of who shall decide-Congress or the courts. Our federalism, which the act expresses, seems to posit generally that in case of doubt, the courts should use state law, leaving new extensions of federal power to the legislative body. See id. 543-46; Hart, supra note 2, at 497-98; and text at note 12 supra.

65. REv. STAT. § 5201 (1875), 12 U.S.C. $\$ 83$ (1952). 
consideration and illegality of the transaction. ${ }^{66}$ The question here is whether the availability of these defenses should be determined by a substantive federal rule or whether state law should be permitted to govern.

In this case, the answer may principally be found in the general congressional legislative pattern. As the Court pointed out:

"The National Bank Act constitutes 'by itself a complete system for the establishment and government of National Banks.'

. . In addition to the sections of the Act conferring on national banking associations the authority to conduct a public banking business the Act contains numerous provisions designed for the protection of the bank's depositors and other creditors. It establishes minimum requirements for the amount of capital with which a bank may begin business . . . and makes special provisions for securing the payment into the bank of the authorized capital. . . . It prohibits the purchase by a bank of its own shares of stock and their retention when purchased. . . . Impairment of capital of an association through its withdrawal by payment of dividends or otherwise is prohibited. . . . Any bank whose capital has become impaired is required under direction of the Comptroller [of the Currency] to make up the deficiency by assessment of its shareholders and in the event of its failure to do so a receiver may be appointed to wind up its business. . . .

"To insure performance of these duties and as a safeguard to creditors and the public, violation of the provisions of the Act by any director or officer of the bank or by any person aiding or abetting him, is made a criminal offense . . . and in the event of such a violation, the association may be required to forfeit all its rights and privileges. . . .

"The obvious purpose of prohibiting the purchase by a bank of its own stock is to prevent the impairment of its capital resources and the consequent injury to its creditors in the event of insolvency. . . ." 67

For present purposes, then, Congress' substantive intention seems clear. Moreover, it has backed its command on this issue with criminal sanctions. The problem in this case then becomes whether there is any reason for leaving to state law the decision of whether there should be the additional deterrent of potential liability on notes given for purposes of concealment. The answer seems to be no. Though the daily lending and similar financial operations of the bank are generally under state 1 law, ${ }^{68}$ its dealings with regard to its organization and capital

66. Deitrick v. Greaney, 309 U.S. 190 (1940). The statement in the text is a slightly simplified version of the case.

67. Id. at 194-95.

68. E.g., Aetna Cas. \& Surety Co. v. Catskill Nat. Bank \& Trust Co., 102 F.2d 527 (2d Cir. 1939); cf. Willing v. Binenstock, 302 U.S. 272 (1937) (pre-Erie); Anderson Nat. Bank v. Luckett, 321 U.S. 233 (1944). 
structure are governed by national rules. ${ }^{69}$ Moreover, the individuals involved in such transactions would have ample notice of that source of law. ${ }^{70}$ Finally, though suits to enforce such liability might be brought in a state court, federal courts are available and would tend to be the more usual forum. ${ }^{71}$

All the considerations thus seem to point in favor of a uniform federal rule for decision, and so the Supreme Court has held. In doing so, it uttered a passage which has been oft quoted since:

"A point much discussed in brief and argument, upon the assumption that local law will guide our decision, see Erie $R$. Co. v. Tompkins . . . is whether by Massachusetts law respondent is precluded from setting up the illegality of the transaction as defense to his note. But it is the federal statute which condemns as unlawful respondent's acts. The extent and nature of the legal consequences of this condemnation, though left by the statute to judicial determination, are nevertheless to be derived from it and the federal policy which it has adopted. . . ." $\mathbf{z}^{2}$

The situations in which Congress has thus clearly expressed its own overriding substantive policy pose comparatively simple problems. Far more troublesome are those issues which, though closely related to a "complete system" established by national legislation, are nevertheless not so clearly governed by its substantive provisions. The very "completeness" of the system will of course have significant bearing, but it is not necessarily determinative per se on all related issues.

Case II

Consider, for example, National Service Life Insurance-quite a "complete system" of legislation "3 -and the following case. A soldier took out a National Service Life Insurance policy, designating his

69. See quotation in text at note 67 supra.

70. A later analogous case omitted this element of notice. Defendant gave a state bank his note, on the understanding that it would not be called for payment, to replace past due bonds (which he had sold the bank) on the books of the bank. Shortly thereafter, the Federal Deposit Insurance Corporation Act was enacted, and the following year FDIC insured the state bank. FDIC later acquired the note as part of collateral security for a loan to the bank and thereafter brought suit on it. The Court held, citing the principal case in the text, that federal law ruled out the asserted defense of want of consideration. D'Oench, Duhme \& Co. v. FDIC, 315 U.S. 447 (1942). Chief Justice Stone and Mr. Justice Frankfurter concurred on the basis of state law only. Mr. Justice Jackson concurred, in an opinion which has been much quoted since, on the basis of federal law.

71. 28 U.S.C. $\$ \S 1348,1345$ (1952), see cases in annotation to those sections in U.S.C.A. and in 12 Federal Digest.

72. Dietrick v. Greaney, 309 U.S. 190, 200-01 (1940) ; cf. D'Oench, Duhme \& Co. v. FDIC, 315 U.S. 447 (1942); Sola Elec. Co. v. Jefferson Elec. Co., 317 U.S. 173 (1942).

73. National Service Life Insurance Act of 1940, 54 Srax. 1008, as amended, 38 U.S.C. $\$ \S 801-23$ (1952). 
mother as beneficiary. Later, while living in Tennessee, he was adjudged incompetent by a state court and committed. He was ultimately discharged from the hospital upon pronouncement by a medical board that he was competent, but that issue was never passed upon by a state court. About a year later, he filed the usual forms to substitute his wife as beneficiary of his government policy. After his death, his wife and mother proceed to litigate the validity of the change. ${ }^{74}$ A major issue is what law-state or federal-should govern on the issue of competence.

It may help sharpen this issue to mention that Tennessee law made the adjudication of insanity conclusive of continued incompetence until overturned by a further judicial determination. But bringing this up raises the common problem that dislike of the particular state rule may tend to impel one toward the application of a federal rule solely because it can provide differently. It may not be amiss to point out that this consideration is theoretically irrelevant ${ }^{75}$ to the general question here: which law should govern.

On that question, once again the first inquiry is into the congressional provisions regarding the subject concerned, in this case servicemen's insurance. Obviously, there is nothing specific in the legislation on the issue of competence to designate beneficiaries, or there would be no problem. As to related matters, the general pattern is less than conclusive. On questions of disposition of proceeds of this insurance, the pattern is clearly federal. For one thing, the statute specifically reserves to the insured the unilateral right to change beneficaries. $^{76}$ Moreover, as originally enacted, the statute specified limited classes of permitted beneficiaries ${ }^{7 \tau}$ and provided its own definitions of some of the relationships involved. ${ }^{78}$ Both in that version and as

74. Dyke v. Dyke, 227 F.2d 461 (6th Cir. 1955). Here again, the facts have been somewhat simplified.

75. This is to be distinguished from consideration of the merits of the state rule vis-a-vis the operation of the federal program. See text at notes 31-34 sicpra. The reference here is to dislike of the particular rule generally, even in the state context. In some ways the problem here is similar to that involved in deciding jurisdictional questions, of which Professor Paul A. Freund has said: "I think we would all be happy if we could establish as a preliminary jurisdictional question the answer to how the Court will decide the merits. I think we have got to recognize the danger of a decision that will not please our heart's desire." SUPREME CouRT AND SUPREMIE LAW 32 (Cahn ed. 1954). In one sense, the problem is even more difficult in the choice of law area, since one can know, as here, the merits of the state law rule.

76. 54 STAT. 1009 (1940), as amended, 38 U.S.C. $\$ 802(\mathrm{~g})$ (1952) (subject to regulations).

77. 54 STAT. 1009 (1940) (later amended by 60 STAT. 782 (1946)), 38 U.S.C. $\$ 802$ (g) (1952) (restrictions not applicable to policies maturing on or after Aug. 1,1946 ).

78. 54 STAT. 1008 (1940), as amended, 38 U.S.C. \$\$ 801 (e), (f) (1952). Note that this was done despite the fact that family law matters are generally deemed of particular state concern, see text at notes 106-12 infra. Even with these federal definitions, however, some state law continued to be applicable upon such matters as marriage. See Note, 68 HARV. I. REV. 1212, 1217-18 (1955). Nevertheless, the general pattern indicated is to use federal law as much as possible. 
amended, the statute undertakes to make explicit provision for disposition of proceeds in the event that the designated beneficiary cannot receive them all, and specifically prevents their escheating to a state. ${ }^{70}$ On the other hand, in matters relating to competence, the pattern is far from clear. The statute of necessity makes some reference to state law; since the federal courts do not take charge of incompetents' estates or appoint guardians to do so, ${ }^{80}$ such action when necessary must be taken in the state courts under local law. ${ }^{81}$ At the same time, some attempt is made to alleviate problems which may arise from this, ${ }^{82}$ and in particular instances, specific reference is made to federal determination of mental capacity. ${ }^{83}$

This dual pattern is reflected in the actual administration of $\mathrm{Na}$ tional Service Life Insurance. The program is centralized through the Veterans' Administration; statutory provisions limit the handling of claims to individuals and representatives of national organizations recognized for the purpose by the Administrator of Veterans' Affairs. ${ }^{84}$ In practice, changes of beneficiaries under National Service Life Insurance are normally made on prescribed forms; if advice is sought by policyholders it will normally be from government officials or national veterans' organizations. At the same time, however, these agencies will also be handling other problems of incompetents. Though some of these problems may involve federal determinations of mental capacity -in relation to such matters as pension claims ${ }^{85}$ and release from veterans' hospitals ${ }^{86}$ —others will bring these agencies into contact with local law on the subject.

Effective administration of the act does not, then, require an independent federal substantive rule; officials already accustomed to referring to state law would not find a substantial burden in applying

79. 54 Stat. 1009 (1940), as amended, 38 U.S.C. $\$ \$ 802(\mathrm{~h})(3),(\mathrm{i}),(\mathrm{j})$, (u) (1952). Note that the statute also provides a federal exemption of proceeds from the claims of creditors. 49 STAT. 609 (1935), as amended, 38 U..S.C. $\$ 454$ a (1952), made applicable by 54 STAT. 1014 (1940), as amended, 38 U.S.C. $\$ 816$ (1952).

80. Cf. Vestal \& Foster, Implied Limitations on the Diversity Jurisdiction of Federal Courts, 41 MrnN. L. REv. 1, 35-36 (1956).

81. See, e.g., 43 StaT. 613 (1924), as amended, 38 U.S.C. $\$ 450$ (1952), made applicable by 54 STAT. 1014 (1940), as amended, 38 U.S.C. $\$ 816$ (1952).

82. Ibid.

83. E.g., 43 STAT. 612 (1924), as amended, 38 U.S.C. § 445 (1952), made applicable by 54 STAT. 1014 (1940), as amended, 38 U.S.C. $\$ 817$ (1952). As to federal rating of incompetence, see 38 C.F.R. $\$ 3.173$ (e) (Supp. 1955).

84. 49 STAT. 2031-32 (1936), as amended, 38 U.S.C. $\$ 101-103$ (1952), made applicable by 54 STAT. 1014 (1940), as amended, 38 U.S.C. $\$ 816$ (1952).

85. See, e.g., 38 C.F.R. $\$ 3.173$ (e) (Supp. 1955).

86. Indeed, in the actual case on which the text problem is based, see note 74 supra, the insured had been released from a veterans' hospital as competent. 
it in this context too. ${ }^{87}$ At the same time, the channels for this insurance being distinct, there would seem to be no particular advantage to the general business community in adhering to local rules. From the point of view of the individual veteran, the balance is also unclear: for the itinerant, a uniform rule might help; for another, the advantage might be with a single handling - under state law-of all his affairs. The statutory scheme itself, though far from conclusive, does seem somewhat persuasive of a congressional leaning toward a single nationwide system on all aspects of this program.

The most significant confirmation of this federal tendency comes from another direction: litigation of this question is exclusively within the jurisdiction of the federal courts; though the United States may in fact be a party only as stakeholder, Congress has provided for these cases to be determined only by the national judiciary. ${ }^{88}$ This alone tends to suggest a congressional determination for implementation of this program without regard to local patterns. To the extent that there may be any differences between state and federal approaches to the underlying considerations, this provision tends to imply a choice in favor of the latter. ${ }^{89}$ Even beyond such inferences, the fact of exclusive jurisdiction itself creates militating factors. For if, under those conditions, state law is adopted, it must of necessity be applied without any possibility of state court consideration of the precise type of case. The use of local rules under these circumstances is thus necessarily attended by speculation as to the weight which state courts might attribute to various factors in the federal situation. ${ }^{90}$

The use of a federal rule may itself involve some uncertainty, at least for a while; it will take time before rules are settled, even by the courts of appeal-and certainly (if ever) by the Supreme Court. ${ }^{91}$ However, ultimate resolution is possible. And in the interim, the

87. This was confirmed in interviews with Veterans' Administration officials in Philadelphia, Pa., December 1956.

88. 43 STAT. 612 (1924), as amended, 38 U.S.C. $\$ 445$ (1952), made applicable by 54 STAT. 1014 (1940), as amended, 38 U.S.C. \& 817 (1952).

89. The granting of jurisdiction to federal courts may have been motivated by a desire to provide for interpleader of defendants living in different states. See ibid. However, this would require only that federal jurisdiction be available, not that it be exclusive. Since the statute does not speak explicitly to this issue, the inference in the text may be built on what was in fact an inadvertent result. Nevertheless, inadvertence alone would suggest that state interests were not considered highly relevant in this context.

For a general analysis of some of the factors pertinent to a grant of exclusive jurisdiction, see Note, Exclusive Jurisdiction of the Federal Courts in Private Civil Actions, 70 HARv. L. REV. 509 (1957).

90. Such as the possible weight which might be assigned to advice of Veterans' Administration officials, federal ratings of competence, etc.

91. Although, even in the interim, decisions across the country would be made with reference to the same source of law, and it seems probable that the number of relevant decisions would grow at least as fast as if reference were made to state law. 
absence of certainty is not of overwhelming importance in this context. For one thing, the major end sought by the use of federal law here is not uniformity per se, but rather sympathetic handling of the federal program. Moreover, to the extent that uniformity might be helpful, in this area (unlike some others) there is some gain even from uniformity within the circuits; for example, though this would not eliminate, it would tend to reduce the problems attendant upon traveling veterans.

All of this is not to make state determinations-and particularly adjudications-irrelevant. Rather it means only that they need not be accorded the same effect or conclusiveness which they may have under state law for other purposes. $^{92}$

On balance, then, ${ }^{93}$ the indicated course seems that of an independent federal substantive rule for decision, and this was the holding of the court presented with this problem. ${ }^{94}$

\section{Case III}

There may be some temptation to generalize from the last case to cover any issue closely related to a "complete scheme" of federal legislation and within exclusive jurisdiction of the national courts. Such an inference is, however, untenable. Copyright law involves both these characteristics, ${ }^{95}$ and yet consider the following problem case: The Copyright Act provides for renewal of a copyright upon expiration of its original term, and provides further that if the author is dead at that time, his widow and "children" shall jointly ${ }^{96}$ succeed to the right of

92. Somewhat similar problems as to the effect to be accorded state determinations arise in the context of the federal tax laws. See, e.g., Oliver, The Nature of the Compulsive Effect of State Law in Federal Tax Proceeding, 41 Calif. L. REv. 638 (1953).

93. The approach followed in this paper is obviously intended to suggest the inadequacy of a blanket approach, such as "All government contracts are governed by federal law; this insurance policy is a government contract." While, of course, some generalizing can, and must, be done, it should also be recognized that contexts vary. Thus, it is probably true that the construction of most contracts with the Government should be governed by federal law: there is generally quite a substantial background of congressional legislation regarding their negotiation; the transaction is frequently interstate; businessmen would generally be able to accomodate to special rules regarding their dealings with the Government; and finally, nearly all such litigation will occur in the federal courts. And so the cases generally seem to hold. See, e.g., Priebe \& Sons, Inc. v. United States, 332 U.S. 407 (1947); Pofcher, The Choice of Law, State or Federal, in Cases Involving Government Contracts, 12 LA. L. REv. 37 (1951). At the same time, the variations which may be required by special contexts should not be ignored. Consider for example, leases or other dealings regarding land in the states. See, e.g., Leiter Minerals, Inc. v. United States, 77 Sup. Ct. 287 (1957); Girard Trust Co. v. United States, 161 F.2d 159 (3d Cir. 1947); and $c f$. the ramifications of the latter in American Houses, Inc. v. Schneider, 211 F.2d 881 (3d Cir. 1954).

94. Dyke v. Dyke, 227 F.2d 461 (6th Cir. 1955); cf. Taylor v. United States, 113 F. Supp. 143 (W.D. Ark. 1953).

95. See 17 U.S.C. $\$ \S 1-215$ (1952) ; 28 U.S.C. $\S 1338$ (a) (1952).

96. This construction of the statute was in fact established in the first part of the case on which the problem in the text is based. See De Sylva v. Ballentine, 351 U.S. 570,573 (1956). 
renewal..$^{97}$ An author, possessed of many original copyrights, died before the expiration of their term. When that time arrives, he is survived by his widow and one illegitimate son, and the issue arises whether the latter is entitled to share in the renewal, as being within the statutory term "children." The statute provides no definition of the term; it must be judicially supplied. The question is then whether that shall be done by an independent federal formulation, or whether state law should be absorbed for the purpose. ${ }^{98}$

The statutory context of this problem is, of course, singularly federal. This is true not only as to copyright legislation generally, but as to the renewal right in particular with its specific provisions for succession upon death displacing more usual rules for devolution of property. At the same time, this succession provision is couched in terms which generally require reference to state law for their precise meaning. Thus, the designation of "widow" or "widower" can ultimately be made definitive only in terms of local rules, ${ }^{99}$ as is also true of the "executor" and "next of kin," ${ }^{100}$ and indeed, of adopted "children" at least. ${ }^{101}$

For this reason alone, there could be no substantial difference in administration of copyrights turning on whether a federal or incorporated state law rule be used on the issue of the problem case. Much more important, however, is the fact that the resolution of such issues is not within the duties of the Copyright Office, which will register any renewal apparently valid on its face. ${ }^{102}$ The resolution of this problem, either way, can then have no effect upon governmental administration in this area. ${ }^{103}$

The argument of "uniformity" has nevertheless been made. ${ }^{104}$ Since it cannot realistically refer to administration, it may conceivably

97. 17 U.S.C. $\$ 24$ (1952).

98. De Sylva v. Ballentine, 351 U.S. 570 (1956).

99. Indeed, the Copyright Act does not even specify its own choice-of-law rules regarding these matters, as do other federal statutes, e.g., Social Security Act, 64 STAT. 492 (1935), 42 U.S.C. \$ 416(h) (1) (1952).

100. Cf. Poff v. Pennsylvania R.R., 327 U.S. 399 (1946).

101. See De Sylva v. Ballentine, 351 U.S. 570, 580 (1956).

102. And in a case like this, all that need be shown on the face of the application is that the applicant is a "child" of the author. See memorandum of Register of Copyrights submitted in De Sylva v. Ballentine, 351 U.S. 570 (1956). Note also that this memorandum did not argue for application of a federal substantive rule.

103. See note 102 supra, and note also that this statute had been in effect for over eighty-five years, and the Register of Copyrights apparently felt no need to decide the issue for purposes of administration. Ibid.

104. See De Sylva v. Ballentine, 351 U.S. 570, 583 (1956) (dissenting opinion). 
be made with reference to the exclusiveness of federal jurisdiction in this area. State tribunals are excluded from entertaining these cases, ${ }^{105}$ and thus, to some extent, the arguments which were relevant to this facet of the preceding problem case may bear some weight here. And yet they cannot be as persuasive, for the reason, at least, that the alternatives are not quite as simple. Though a decision in favor of a federally formulated rule may seem a complete answer, such "uniformity" may prove quite illusory. For if that rule were to be that only "legitimate" issue were included, it would still leave the question of whether any children legitimated after birth were "legitimate" in the sense of the rule. Unless that possibility were totally excluded, then the question of what constitutes legitimacy would probably have to come down to the rules of state law. ${ }^{108}$ Thus, on this issue, as on questions of adoption, the choice of a single federal "rule" may not necessarily mean uniformity in result, but only postponement to a second stage of the reference to state law. Moreover, even if a federal formulation were chosen which would obviate this necessity-such as including all natural children or only those actually born in wedlock-the result would still be an "island" of federal law regarding natural issue amid a larger area of incorporated state law on adopted children, marriage and the like, defining all other relationships under the section.

More important here is the viewpoint of the individuals concerned. Though a veteran's competence may be determined federally in some contexts and locally in others, it is to state law that men are accustomed to look on the question of who are their children: questions of custody, support, inheritance and other legal facets of the relationship are all determined by the rules of the local jurisdiction. There would seem to be no good reason for introducing the additional complication of a separate federal rule; ${ }^{\mathbf{1 0 7}}$ to the extent that the object of the renewal

105. 28 U.S.C. $\S 1338$ (b) (1952). Of course, exclusive federal jurisdiction applies only to cases which "arise under" the copyright laws. Cf. Mishkin, supra note 15, at 163-76. Although it is conceivable that this issue might arise in state court litigation, see Note, 70 HARv. L. REv. 509, 510-11 (1957), it would seem much more likely to appear in an action for infringement or other suit "arising under" the federal legislation.

106. It might, of course, be possible to prescribe specific federal rules for all the possible situations; however, there seems no substantial reason for (and as the text indicates, quite a bit against) having such special rules in this context different from all others. Compare the reference to local law on similar issues in what is certainly a "most federal" context, immigration and naturalization. 66 STAT. 166 (1952), 8 U.S.C. $\S \S 1101(\mathrm{~b})(1),(\mathrm{c})(1)(1952)$.

107. Indeed, to the extent one gives credence to the theory that authors as a class are particularly likely to be uninformed or unconcerned about legal matters, this could provide strong reason against such additional complication. Some support for this view could be mustered from the reasons for which Congress chose to provide two copyright periods (rather than one long one), and frem the fact that it did not allow the renewal 
provisions is to add to the reward of an author by providing for the "natural objects of his bounty," 108 his actions in compliance (or omission) under state law would seem sufficient to establish whether he considered his illegitimate child as being within that class.

At the same time, adoption of state law-since it is a matter of federal judicial discretion-need not carry with it the uncertainties sometimes found regarding domestic relations matters. As was indicated earlier, the choice of law rule which identifies the determinative contact in the situation may well be federal; the relevant state, and indeed, the pertinent portion of its family law (where more than one is possible) could thus be clearly determined in advance. ${ }^{109}$ The relevant parties could thus be known whenever that might be necessary, as in advance assignments of these renewal rights, ${ }^{110}$ about as readily as under a federal substantive rule. ${ }^{111}$

The balance here thus seems to fall in favor of absorbing local law as the rule for decision. And so the Supreme Court held. The Court's opinion spelled out so clearly the implications of federal adoption of state law-as distinguished from that law applying of its own forcethat it seems worthwhile quoting extensively:

"We come then to the question of whether an illegitimate child is included within the term 'children' as used in [the statute]. The scope of a federal right is, of course, a federal question, but that does not mean that its content is not to be determined by state, rather than federal law. . . . This is especially true where a statute deals with a familial relationship; there is no federal law of domestic relations, which is primarily a matter of state concern. . . .

rights to devolve in the same manner as ordinary property. See the legislative history of the renewal provision described in both majority and dissenting opinions in $M$. Witmark \& Sons v. Fred Fisher Music Co., 125 F.2d 949 (2d Cir. 1942). However, this theory is nonetheless far from indisputable. See, e.g., the opinion of the Supreme Court affirming in that same case. 318 U.S. 643, 656-7 (1943).

108. Moreover, to the extent that the problem may be that of an author's illegitimate children becoming public charges if cut off from renewal rights, that too is primarily a matter of state concern, which each state has presumably decided for itself by its general rules as to inheritance by illegitimate offspring in that jurisdiction.

109. Moreover, as also indicated, any particular aberrational rules could be rejected for incorporation. (1943).

110. Held possible in Fred Fisher Music Co. v. M. Witmark \& Sons, 318 U.S. 643

111. Indeed, in practical terms probably more readily than under a uniform federal rule which included as "children" all natural offspring, since state law frequently requires some sort of public acknowledgment for legitimation or inheritance. See the various Briefs Amicus Curiae, De Sylva v. Ballentine, 351 U.S. 570 (1956). 
"We think it proper, therefore, to draw on the ready-made body of state law to define the word 'children' in $\$ 24$. This does not mean that a State would be entitled to use the word 'children' in a way entirely strange to those familiar with its ordinary usage, but at least to the extent that there are permissible variations in the ordinary concept of 'children' we deem state law controlling.

"This raises two questions: first, to what State do we look, and second, given a particular State, what part of that State's law defines the relationship. tinued] :

[After considering the available alternatives, the Court con-

"Considering the purposes of $\$ 24$ of the Copyright Act, we think it sufficient that the status of the child is that described by $\$ 255$ of the California Probate Code. The evident purpose of $\S 24$ is to provide for the family of the author after his death. Since the author cannot assign his family's renewal rights, $\$ 24$ takes the form of a compulsory bequest of the copyright to the designated persons. This is really a question of the descent of property, and we think the controlling question under state law should be whether the child would be an heir of the author. It is clear that under $\S 255$ the chid is, at least to that extent, included within the term "children.' " 112

\section{Case IV}

The next problem case is somewhat more complex. Government ${ }^{113}$ "bearer" bonds were stolen from the Bank of America, and next appeared in the possession of one Rocco, who engaged Parnell to present them for collection. Parnell did so through a Pennsylvania bank, which in turn forwarded them to the Federal Reserve Bank of Cleveland. Although the bonds were not due to mature until after these transactions-and that was what appeared on their face-they had in fact been called for redemption (in accordance with their terms) before these events. The Federal Reserve Bank cashed the bonds and paid the Pennsylvania bank, which paid Parnell, who in turn paid Rocco. Suit by the Bank of America against Parnell and the Pennsylvania bank.114

112. Id. at 580-82. The opinion of the Court was by Mr. Justice Harlan.

113. In the actual case, the bonds involved were issued by the Home Owners Loan Corporation, a government corporation, with principal and interest guaranteed by the United States; all courts concerned treated the case as if government bonds were involved.

It should be noted, however, that there may be circumstances when Congress' choice of separate corporate form will be significant. Cf. Keifer \& Keifer v. RFC, 306 U.S. 381 (1939).

114. Bank of America v. Parnell, 352 U.S. 29 (1956). 
Here the question of the source of the applicable rules for decision has two aspects: (1) the nature of the bonds, including their negotiable character and "overdueness"; and (2) the relations between private parties dealing in bonds of the nature thus established, including matters of "good faith" on the part of Parnell and the Pennsylvania bank and the burden of proving it. ${ }^{115}$

As to the nature of the bonds, there would seem to be comparatively little difficulty. Federal statutes and regulations provide for their issuance as negotiable instruments, and specify many of the incidents of the obligation. ${ }^{116}$ This background, together with the strong argument for uniformity in these matters as to all bonds of the same issue, would seem sufficient to authorize independent federal judicial determination of any such matters not provided for legislatively. ${ }^{117}$

But this reasoning does not carry over to the second aspect. It is one thing to say that federal law will be used to establish the general character of the bonds, and quite another to say that in the absence of congressional legislation it will also specify the consequences of that character in dealings between private parties. ${ }^{118}$ The point may be dramatized by instancing the case of money. Federal law clearly establishes money as legal tender ${ }^{118}$ —a status which state authority must recognize-but it is local law which determines what the effects of money transactions are. Indeed, any attempt to subject to national rules the relations between private parties successively handling money ${ }^{120}$ would seem anomalous within our existing federal structure, as constituting an unwarranted intrusion into areas traditionally and

115. This breakdown is similar to that used in choice of law among the states. See opinion of Judge Goodrich in the principal case of the court of appeals, 226 F.2d 297, 303 (3d Cir. 1955) and note 117 infra.

116. 48 STaT. 129 (1933), as amended, 12 U.S.C. \& 1463 (c) (1952); e.g., 31 C.F.R. $\$ \S 306.0,306.2,306.25$ (Supp. 1956).

117. This is also supported by the choice-of-law rule among the states which would tend to refer to the state of issuance of bonds for the law governing such matters. Restatement, Conflict of Laws \$ 348 (1934); Goodrich, CoNFLiCT of LAws 341-42, 499 (3d ed. 1949) ; cf. StuMrBERG, Conflict of Laws 246-56 (2d ed. 1951).

118. Although the term "private parties" is used, the same might well apply to the Government when not acting in its capacity as obligor-e.g., if the HOLC purchased its own bonds on the market (as the statute authorizes. See discussion of the Clearficld case, text at notes 132-47 infra).

119. 48 STAT. 52 (1933), as amended, 31 U.S.C. § 462 (1952).

120. Nor is this possibility merely the wild flight of a law professor's imagination. In a case decided by the Sixth Circuit in 1952, the action was between a bank from whom currency had been stolen and a company to whom the currency had been surreptitiously given by the thief to conceal earlier defalcations. One of the possible issues was choice of governing law, and one judge (dissenting, to be sure) said: "The rights of the parties in the stolen currency are governed by federal rather than local law"citing Clearfield Trust! Stone \& Webster Engineering Corp. v. Hamilton Nat. Bank, 199 F.2d 127, 133 (6th Cir. 1952). 
properly regarded as state domain. ${ }^{121}$ Though the impact of a similar position as to government bonds would hardly be as great, the analogy seems close enough to require substantial reasons to justify the application of federal rules to the relations of parties handling these bonds.

The major reason which has been offered invokes the national importance of free circulation of government bearer bonds, which it is argued, cannot be assured if state law prescribes the consequences of transactions in this paper. ${ }^{122}$ To the extent this argument is based on present conditions, the answer may be simply factual: huge amounts of corporate and municipal bearer bonds now circulate freely throughout the country, apparently unimpeded by the governance of local law. ${ }^{123}$ To the extent that the argument proceeds from possibilities of state law interference, the response is twofold. First, and probably most important, such interference could only occur by impeding the channels for all bearer bonds; state rules may not in any event discriminate against the national government. In the unlikely event that state law chooses to hinder circulation of all bearer paper, both congressional and national judicial power remain available to protect the federal issues. ${ }^{124}$ It hardly seems necessary to formulate an independent body of law now in order to protect against that remote possibility.

Moreover, the disadvantages of prescribing federal substantive rules for decision seem substantial. On the practical level, it would mean that government bonds, though generally handled in the same channels as corporate and other bonds, might in important respects require different treatment. So long as state law channels remain adequate, there would seem to be no reason to create this added complexity.

There are, moreover, other implications. If federal law is applied to all dealings with these bonds, then every case growing out of such dealings would "arise under" federal law and thus come within the jurisdiction of the national courts. ${ }^{125}$ To the extent that government

121. This is not to say that Congress might not be able to prescribe more than it has; only that would be improper for the courts to attempt to reach so far.

122. See opinion of the majority of the court of appeals in the principal case, Bank of America v. Parnell, 226 F.2d 297, 299 (3d Cir. 1955); Brief for Respondent, pp. 35-37, Bank of America v. Parnell, 352 U.S. 29 (1956).

123. Apparently no official records are available showing the precise percentage of non-government bonds circulating which are in bearer form. Unofficial estimates from brokers and other experts were generally in the range of about 90 per cent of publicly issued bonds.

124. Moreover, as previously pointed out, no part of state law need be adopted which is inconsistent with the federal operation.

125. Under the general jurisdictional statute, this would not be so if state law applied, even by way of federal incorporation. Mishkin, supra note 15, at 165-66. 
bonds, traveling in the same channels as other similar paper, might be involved in the same events with local law bonds, this could create significant problems in judicial administration. ${ }^{126}$ Even when government paper is not so intermingled with others, the consequence would tend to be transfer of many cases ${ }^{127}$ from state to federal tribunals. Aside from impact on state court responsibility, this would involve a significant increase in the business of the national courts. While this fact may not constitute a good theoretical argument against resort to those tribunals for protection of federal rights, it does have certain relevant implications. Very important is that it could add measurably to the already huge burden carried by the Supreme Court. ${ }^{128}$ It would then have an impact on, and in a sense be considered at the expense of, other areas of Supreme Court responsibility. At the same time, it would mean that the likelihood of any "federal rule" in this area being in fact uniform across the country is not too high.

These results might not follow if there existed a well-developed and fairly settled body of up-to-date precedent; under such circumstances, occasional resolution of conflicts among the circuits would suffice. The available source indicated by the Supreme Court, however, appears to be the federal law merchant developed in the run of litigation under Swift $v$. Tyson, and even that authority apparently may not be considered automatically applicable to government paper under

126. Thus if, for example, federal bonds and corporate paper were stolen and later negotiated at the same time, there would be a choice (absent diversity of citizenship) of (1) suing on both claims in a state court, which would then have to apply federal law to the government bonds and state law to the rest; or (2) trying to bring both into a federal court, on the theory that "pendant jurisdiction" of the federal claim will encompass the state law claim, too-a questionable possibility, see Hurn v. Oursler, 289 U.S. 238 (1933) ; or (3) pursue two separate lawsuits with the extra expense involved, and conceivably with some risk of being held to have "split the cause of action."

127. Whatever lines of analysis to these particular bonds would presumably apply more widely to other forms of government paper, at least, and quite possibly further.

128. It has been authoritatively suggested that broadening the intake of the lower federal court tends to increase the burden of the Supreme Court. Frankfurter \& Landis, The Business of THE SUPREME Court 3, 60 (1927); Frankfurter, Distribution of Judicial Pozer Between United States and State Courts, 13 CORNELL L.Q. 499, 506 (1928).

In the context of the problem under discussion, there might not be a significant difference in Supreme Court work load if one anticipated frequent substantial contention in the state courts that particular issues between private parties (relating to government paper) should be governed by a federal rule, for this in itself would be a federal question to be resolved ultimately by the Supreme Court. However, such contention would have to be premised on the theory that either (a) the particular issue was especially close to the federal program; or (b) state law on the issue was inconsistent with the national program. Here, unlike other areas of federal incorporation, a decision in favor of using state law would tend to govern a whole area of privateparty relationships, rather than single issues. And the latter contention seems unlikely to be often of substance in an area governed largely by uniform laws on commercial instruments, apparently adequate for the maintenance of an effective market in private paper. See text at notes $122-24$ supra. 
present day conditions. ${ }^{129}$ In this light, it may well be doubted whether the Supreme Court could effectively undertake, without unwarranted sacrifice, to build a reasonably solid body of authority in this area. And until it did so, neither uniformity nor certainty could be sure to characterize the area.

On the other hand, the area of negotiable instruments is one in which the law of the several states is not as diverse as in many other fields; the Uniform Negotiable Instruments $\mathrm{Law}$ has been adopted across the nation, and though interpretations on specific points may vary, it would most probably provide a more certain, and possibly even more uniform body of rules than would be produced by an independent formulation of a contemporary federal common law on the subject. Moreover, it would be a body of rules under which individuals handling these bonds are accustomed to operate, and which seem quite adequate for the purpose. ${ }^{130}$ From both points of view, then, the use of state law as the governing rule for decision seems clearly indicated as to relationships between parties handling this federal paper. It should come as no surprise that the Supreme Court has so held. ${ }^{131}$

\section{Case V}

The final problem to be treated is the specific issue of the Clearfield Trust case. ${ }^{132}$ A WPA paycheck, drawn on the Treasurer of the United States, was issued at Harrisburg, Pennsylvania, payable through the Federal Reserve Bank of Philadelphia. It was mailed to the payee, but was intercepted by someone else who, forging the endorsement, cashed it at the J. C. Penney store in Clearfield, Pennsylvania. Penney endorsed the check over to the Clearfield Trust Company, which in turn endorsed it to the Federal Reserve Bank of Philadelphia, "Prior Endorsements Guaranteed," collected the face amount and paid it over to Penney. About twelve days after the check had been drawn, the

129. "And while the federal law merchant developed for about a century under the regime of Swift $v$. Tyson ... represented general commercial law rather than a choice of a federal rule designed to protect a federal right, it nevertheless stands as a convenient source of reference for fashioning federal rules applicable to these federal questions." Clearfield Trust Co. v. United States, 318 U.S. 363, 367 (1943). (Emphasis added.)

130. If an increased predictability were considered important for this area, it might be possible-in comparatively few decisions-to establish federal choice of law rules for multi-state transactions of this sort. The necessity or desirability of such formulation for this area is open to substantial question.

131. Bank of America v. Parnell, 352 U.S. 29 (1956).

132. As to the general issue, see text at notes 10-19 supra. 
intended payee notified officials of his WPA project that he had not received the check. Six and one-half months later, he executed an affidavit stating that the endorsement was a forgery. Clearfield Trust was first notified of the forgery six weeks after that, and was first told that the United States was asking reimbursement more than six months later. It refused to pay and the Government sued. Under Pennsylvania law the delay in notification constituted a complete defense to such a suit, and the question arises whether that law or an independently formulated federal rule should be applied. (As indicated earlier, the Clearfield decision first settled the power of the federal courts to make the choice; the issue we are concerned with here is what that choice should be.)

There is, of course, no specific congressional provision for this case. Nor does any other federal legislation appear particularly apposite. $^{133}$ The silence of Congress does not, however, automatically mean that the courts should refrain from adopting a federal rule; the federal judiciary has a real responsibility for a living common law in the area of its concern, which rules out any general premise that congressional failure to act precludes judicial action. ${ }^{134}$ At the same time, though that automatic inference may be unavailable, specific circumstances may give rise to fairly reliable indications. This would certainly be true when legislative action has been specifically considered and rejected in favor of continuance of local rules. But it may also apply without quite so clear a history. There may indeed be times when the fact that a problem was not even raised could be significant; for example, where the interest most vitally concerned is one which has demonstrated an ability to get congressional consideration of its problems, particularly in the same subject matter area.

This last seems to be the precise situation in this case. The Treasury does have access to Congress' ear regarding matters in its bailiwick - to a degree probably not exceeded by any other department or group. To be sure, the number of problems which can be effectively presented is limited, and there are many matters which must be advanced. Nevertheless, the failure to raise this subject suggests that the Treasury does not place a very high priority on the need for uniform substantive rules in cases such as this. Moreover, there is some evidence that Congress is not entirely disinterested in matters of this sort once brought to its attention: while Clearfield was pending, a federal statute

133. For a careful analysis of the statutory sources cited by the Court, see Note, Clearfield: Clonded Field of Federal Common Law, 53 Colum. L. Rrv. 991, 1002-05 (1953).

134. Cf. HART \& WechSLER, op. cit. supra note 2 , at 706-08. 
was enacted setting up a fund to take care of individuals in the position of the payee in the case. ${ }^{135}$ On balance, then, the congressional silence here, though far from conclusive, does tend to raise doubts about any real necessity for a uniform substantive rule for decision in the circumstances of the problem case.

The Court's opinion in Clearfield did not seem to share these doubts.

“. . . reasons which may make state law at times the appropriate federal rule are singuarly inappropriate here. The issuance of commercial paper by the United States is on a vast scale and transactions in that paper from issuance to payment will commonly occur in several states. The application of state law, even without the conflict of laws rules of the forum, would subject the rights and duties of the United States to exceptional uncertainty. It would lead to great diversity in results by making identical transactions subject to the vagaries of the laws of the several States. The desirability of a uniform rule is plain." 136

With the hesitancy with which one dissents from a proposition approved by an undivided court, ${ }^{137}$ it must nevertheless be submitted that the answer is not quite so plain. It is certainly true that government transactions are frequently multi-state. However, though the scale may be greater, the general problems do not seem much different from those encountered by any of our larger corporations. If the issue were the formulation of general nationwide rules for all interstate negotiable instruments, the argument would seem to carry great weight. ${ }^{138}$ But that was not within the compass of the issue before the Court. And so long as local rules continue to govern in all other matters, the gain from a federal rule as to government checks does not seem so obvious or substantial.

Consider the precise issue of this case. The Court rejected the Pennsylvania rule of delay as a complete defense in favor of a rule that required proof of actual damage. Aside from possible "uniformity," the advantages of the federally formulated rule seem far from clear. The administrative operation of the Treasury would apparently be the

135. 55 STAT. 777 (1941), 31 U.S.C. $\S \$ 561,562$ (1952).

136. 318 U.S. at 367 .

137. (Two Justices did not participate.) It is interesting to speculate when an opinion of the Court gets more attention in detail-when written for an undivided bench or over articulated dissent.

138. This was one of the major arguments for Swift v. Tyson. And cf. Dickinson, The Law of Nations as Part of the National Law of the United States, 101 U. PA. L. REV. 26, 792 (1952-53). 
same under either of the available rules: in either event, effort should be made promptly to notify previous endorsers regarding known forgeries. ${ }^{139}$ The only real gain would seem to be in the work of legal counsel to the Treasury, and in a certain symmetry of the law. While both of these certainly have appeal and perhaps some real value, their importance may be overrated.

For one thing, even the apparent gain may prove illusory. In holding for the Government in Clearfield, the Court stressed that, so far as appeared, the Clearfield Trust Company could still recover from J. C. Penney. Suppose for a moment that such was not the case, but that state law would bar recovery against prior endorsers. ${ }^{140}$ If the implication of the Supreme Court's statement is that under these circumstances the United States could not recover from the defendant, then even surface "uniformity" disappears; the actual operation of the federal rule will depend upon the potentially different rules of the various states as to rights between successive endorsers.

If, on the other hand, state law is to have no effect upon holding for the Government in this type of situation, two possibilities remain. The first is that the uniform federal rule will prevail where the United States is suing, but that in subsequent suits between private endorsers on government checks, state law will govern-possibly taking into account the federal determination. If state law fails to take the United States' recovery into account, then the net result is that the burden of financial loss will merely be shifted from the Government to the particular endorser whom it chooses to sue. If state law seeks to avoid this result by taking into account the operation of the federal rule, then the suit between the private endorsers becomes subjected to greater complexity in its governing law. ${ }^{141}$ Should this be the outcome, it seems merely to shift the problems of complexity from out of the government's view to the banks or private individuals concerned. On such a choice, it seems open to substantial doubt that the latter are better able to bear that burden.

139. The Brief for the Government in the Supreme Court did not give any explication of administrative gains to be had from the federal rule.

140. This was precisely the situation in a more recent case: all prior endorsers (except the forgers) were banks protected, by the terms of state law, from suit after one year (which period had elapsed before the United States had notified the defendant bank, though not before the Government had discovered the forgery). Fulton Nat. Bank v. United States, 197 F.2d 763 (5th Cir. 1952).

141. In the words of the government brief in Clearfield: ". . there will be no greater complexity than in the ordinary case of conflict of laws problems relating to negotiable instruments. . . "This was in a footnote. In the text of the brief, the great complexity of the conflicts rules relating to negotiable instruments was stressed as a prime reason for a single federal rule being applied in the Government's case. Brief for Respondents, pp. 8,23 \& n.12. 
The second possibility-applying federal law to all relations between private parties dealing with a government check-avoids the mere passing on of burdens. However, such an approach seems indistinguishable- both analytically and factually-from. that considered and rejected in the preceding problem case. For those same reasons, it must be rejected here.

Thus, on closer examination, the use of federal law in the Clearfield situation can have one of two possible kinds of result: either it provides only the illusion of uniformity, or it achieves its substance-for the Government-by the process of passing the burdens onto private shoulders. It may well be doubted whether either of these results is sufficiently advantageous to justify selection of an independent federal substantive law for this case. Rather, it would seem that the adoption of local rules for decision of this type of case could produce most, if not all, of the desired gains without the concomitant losses.

Certainty, in the sense of predictability, for government operations could readily be achieved by the adoption of uniform federal choice-oflaw rules, specifying the particular contact in multi-state situations which will be determinative for the purpose of choosing which state's law applies. Indeed, such a body of choice-of-law rules could be established on a firm base-and kept up-to-date-by fewer Supreme Court decisions than would be necessary for a constantly current uniform common law of negotiable paper. ${ }^{142}$ Since, on the whole, local law in this field is fairly well developed, predictability would seem more easily realized via that route than by displacing state law with rules fashioned out of the doctrines developed under Szerift $v$. Tyson. ${ }^{143}$

At the same time, selection of the crucial choice-of-law contact could be made on a basis which would produce the highest probability of "dovetailing" the result in the Government's suit with subsequent liability rules for other endorsers. And this could be accomplished without any risk of actual impediment to government administration. As indicated earlier in this paper, adoption of state law does not entail the incorporation of any rules inconsistent with the needs of the going federal program.

142. In fact, the period since the Clearfield decision has not seen a significant increase in the number of decided cases in the Supreme Court involving the specific problems of federal negotiable instruments law. One case has been decided with full opinion in the precise area of forged government checks, two years after Clearfield. National Metropolitan Bank v. United States, 323 U.S. 454 (1945). It is, of course, practically impossible to know whether there has been an increase in the number of attempts to get Supreme Court review of such questions (which would itself be an addition to the Court's load).

143. See note 129 sipra. 


\section{Present State of the Law; Concluston}

The preceding cases have been presented in a sequence dictated by analytical considerations, and not in the order in which they arose and were decided. ${ }^{144}$ At the time that Clearfield was actually determined, the question of using federally formulated rules for decision in suits between private parties dealing with government instruments had not been dealt with explicitly. Indeed, there is good reason to believe that at least some of the Justices (including the author of the opinion) decided Clearfield on the theory that federal rules of substance would extend to every transaction involving government paper. ${ }^{145}$

The fact is, however, that when that issue was presented thirteen years later as to government bonds, it was resolved, as indicated above, in favor of using state law. Since suits between private parties on government checks seem indistinguishable, the decision of the second issue in Clearfield - that a federal substantive rule be formulated-must be deemed to have been sapped of much of its vitality. ${ }^{146}$ The enduring contribution of Clearfield is its clear establishment of power in the federal courts to select the governing law in matters related to going operations of the national government. Inferentially, then, it also establishes that a choice of state law-to be incorporated in federaldoes not necessarily entail adoption of all the doctrines developed with reference to the Erie domain of state law governing of its own force. With that freedom declared, the problem becomes one of identifying the determinative factors, a quest which can only be fully accomplished by careful examination of all relevant data and full exploration of the implications of choice. ${ }^{147}$

144. The actual sequence was not too dissimilar: (1) the National Bank case, Supreme Court, 1940; (2) Clearfield, Supreme Court, 1943; (3) National Service Life Insurance case, 6th Circuit Court of Appeals, 1955; (4) copyright renewal case, Supreme Court, June 1956; (5) the government bonds case, Supreme Court, November 1956.

145. Mr. Justice Douglas, who wrote the Clearfield opinion, joined with Mr. Justice Black in dissenting from the decision in Bank of America v. Parnell (Case No. IV), on the following basis: "The virtue of a uniform law governing bonds, notes, and other paper issued by the United States is that it provides a certain and definite guide to the rights of all parties rather than subjecting them to the vagaries of the laws of the many States. The business of the United States will go on without that uniformity. But the policy surrounding our choice of law is concerned with the convenience, certainty, and definiteness in having one set of rules governing the rights of all parties to government paper, as contrasted with multiple rules. If the rule of the Clearfield Trust case is to be abandoned as to some parties, it should be abandoned as to all and we should start afresh on this problem." 352 U.S. 29, 35 (1956).

146. As indicated earlier, if this holding is to apply only in suits to which the United States is a party, then actual uniformity is possible only by the shifting of burdens from the Government to private shoulders. See text at notes 140-41 supra.

147. And in this, almost needless to point out, a prime responsibility lies with counsel trying these cases. 
This is a comparatively new and a developing area. There is no substantial reason to expect that here, any more than elsewhere in the law, all the best answers will be found from the outset. Perhaps all that can be asserted with any degree of certainty is that here is undoubtedly a major area for creative responsibility on the part of the national judiciary. Hopefully, in the best tradition of the common law, continued experience and analysis will help to establish the wisesteven though not the most symmetrical-lines of demarcation. 